\title{
Beneficial Effect of Silicon Application and Intermittent Irrigation on Improving Rice Productivity in Indonesia
}

\section{Efek Benefisial Penambahan Silika dan Penerapan Pengairan Berselang terhadap Peningkatan Produktivitas Padi di Indonesia}

\author{
Adha Fatmah Siregar ${ }^{1, *}$, Ibrahim Adamy Sipahutar ${ }^{1}$, Husnain $^{1}$, and Tsugiyuki Masunaga ${ }^{2}$ \\ ${ }^{1}$ Indonesian Soil Research Institute, Jl. Tentara Pelajar No. 12, Bogor 16114, Indonesia \\ ${ }^{2}$ Faculty of Life and Environmental Science, Shimane University, Shimane 690-8504, Japan
}

Received 30 January 2020/Accepted 20 April 2020

\begin{abstract}
It is believed that silicon (Si) application could increase rice production, however studies related to those topics are still limited. The study determined the combination effect of Si application and water management on rice growth and productivity. This study was conducted at the experimental station of Indonesian Agricultural Environment Research Institute, Jakenan, Pati, Central Java at dry season. A split-plot in randomized complete block design with four replications was set. The main plots were different types of irrigation and subplots were Si fertilizer application. Results showed that the application of Si increased plant resistance on blast disease. This current result might be due to the increasing of Si concentration in leaves. IT water management significantly increased the yield compared to CF. IT increased root growth and gave an impact on increasing of plant growth and rice yield. Moreover, IT significantly increased $\mathrm{Cu}$, $\mathrm{Mn}$, and $\mathrm{Zn}$ concentration in rice grain. Combination of Si application with IT water management could increase rice plant productivity especially in area with water shortage.
\end{abstract}

Keywords: blast disease, lodging, rice productivity, silicon application, water management

\section{ABSTRAK}

Penggunaan pupuk silika dipercaya dapat meningkatkan produksi padi, tetapi penelitian pengaruh silika pada tanaman padi di Indonesia masih terbatas. Penelitian bertujuan mengetahui pengaruh kombinasi pemberian pupuk silika dan pengelolaan air pada pertumbuhan dan produktivitas tanaman padi. Penelitian yang dilaksanakan di kebun percobaan Balai Penelitian Lingkungan Pertanian, Jakenan, Pati, Jawa Tengah pada musim kering. Percobaan menggunakan rancangan petak terbagi dengan empat ulangan. Sebagai petak utama adalah perbedaan pengelolaan air sedangkan anak petak adalah perlakuan pupuk silika. Hasil penelitian menunjukkan bahwa pemberian silika meningkatkan ketahanan serangan penyakit blas. Pemberian silika nyata menurunkan serangan blas daun dan leher yang diduga karena adanya peningkatan Si daun. Pengelolaan air berselang (IT) nyata pada meningkatkan hasil dibandingkan pengelolaan air konvensional (CF). Perlakuan IT meningkatkan pertumbuhan akar dan berdampak pada peningkatan pertumbuhan dan hasil padi. Perlakuan IT juga nyata meningkatkan kandungan hara $\mathrm{Cu}, \mathrm{Mn}$, dan Zn pada beras. Kombinasi pemberian silika dan pengelolaan air IT meningkatkan produktivitas tanaman padi terutama pada daerah dengan ketersediaan air terbatas.

Kata kunci: pemberian silikon, penyakit blas, pengelolaan air, produktivitas padi, rebah

\section{INTRODUCTION}

In regards to high annual precipitation, Indonesia is suitable for rice cultivation and continuous flooding is an irrigation method applied by farmers. It is known that rice grows with the largest water consumption, therefore the present challenge for rice cultivation is to produce more rice with less water consumption. Mostly, Indonesian farmers

\footnotetext{
*Corresponding author. e-mail: adha_siregar@yahoo.com
}

conduct rice cultivation under continuous flooded condition, then intermittent water management is not fully adopted due to less dissemination related to this water management. Arief et al. (2013) reported that intermittent could enhance water use efficiency index significantly by up to $37.7 \%$ in the rainy season and could manage water using to $26.07 \%$ compared to continuous flooding.

Under continuous flooding, rhizosphere soil redox will decrease, enhanced the concentration of extractable $\mathrm{Fe}^{2+}$, low zinc availability that will affect grain quality for micronutrient content and inhibit root growth due to the 
lack of oxygen (Rahman et al., 2013). Recently, rice grain quality has become a subject of importance since it affects the nutritional and economic value.

Intermittent water management allows paddy field to be saturated or under shallow standing about thirty days then dry it for particular periods instead of continuously flooding (Arif et al., 2013). This pattern could give advantages for rice growth due to the aerobic condition which could promote the improvement of root system, enhance shoot activities as optimal water and oxygen are available and increase grainfilling rate (Mishra, 2012; Zhang et al., 2012).

Silicon ( $\mathrm{Si}$ ) as a beneficial nutrient is also required to increase rice productivity. $\mathrm{Si}$ is not recognized as an essential nutrient for plant biochemical need but it is absorbed from soil in enormous quantity that are several fold higher than those of other essential macronutrients in certain plant species. There has been a noticeable number of research showing the promising effect of Si on preventing abiotic and biotic stress such as lodging, drought and fungal and insect attack (Salman et al., 2012; Guntzer et al., 2012).

Regarding $\mathrm{Si}$ application, Indonesian farmers less account of using Si for rice field as there is limited applied research on the role of Si on rice growth. Darmawan et al. (2006) stated that there is a decreasing on soil Si availability up to $11-20 \%$. Recent condition shows that there is an indication of Si deficiency on paddy's field was reflected by blast disease occurrence. The objective of this research was to study the effect of silica and intermittent watering application on growth, productivity and quality of rice.

\section{MATERIALS AND METHODS}

\section{Experimental Sites}

Research was conducted during the dry season from March to July in 2015 at experimental station of Indonesian Agricultural Environment Research Institute, Jakenan, Pati, Central Java Province, Indonesia (06 46'66.7' S$\left.111^{\circ} 11^{\prime} 91.4^{\prime \prime} \mathrm{E}\right)$.

Experiment was arranged in a split plot in randomized complete block design with four replications was set. Ciherang rice variety was plant in this research. As the main plot, three water management namely continuous flooding (CF), intermittent (IT) and aerobic rice (AR) were employed. The subplot consisted of $\mathrm{Si}+$ and $\mathrm{Si}$ - (with and without $\mathrm{Si}$ fertilizer). Imported silica gel from Japan "Super Inergia" contains $90 \%$ of $\mathrm{SiO}_{2} \cdot \mathrm{nH}_{2} \mathrm{O}$ was used as $\mathrm{Si}$ source. The plot size was $4 \mathrm{~m}$ x $5 \mathrm{~m}$ for each treatment and completed with inlet and outlet at each plot for irrigation purposes. To avoid interference with other treatments, a plastic sheet was placed about $30 \mathrm{~cm}$ into the soil along the plot.

$\mathrm{CF}$ was set with basin system and water level was maintained around $5 \mathrm{~cm}$ in depth from planting to 15 days before harvest. IT treatment was set by maintaining $5 \mathrm{~cm}$ in depth for three days followed by seven days without additional watering. This pattern was repeated until panicle initiation stage. As heading stage of rice is completed, then the field was set under flooded condition about $5 \mathrm{~cm}$ water in depth. Approaching to harvest time, the outlet was opened for fifteen days. Meanwhile for AR water management, from transplanting until tillering stage, the field was in anaerobic condition with $5 \mathrm{~cm}$ water depth. After tillering stage, the water supply was managed by keeping the water level at 15 $\mathrm{cm}$ below soil surface and irrigation will be added if water level less than $15 \mathrm{~cm}$ below soil surface. To monitor the water level, a field water tube was installed. Prior to harvest time, the outlet was opened.

\section{Plant Cultivation}

Field was prepared with two times plowing followed by leveling. Five hundred kilograms per hectare of silica gel was applied by broadcasting one week before transplanting. This study used three weeks old of rice seedling then transplanted as two seedlings with planting space as $20 \mathrm{~cm}$ x $20 \mathrm{~cm}$. The fertilizer dosage was $350 \mathrm{~kg} \mathrm{ha}^{-1}$ of urea, 100 $\mathrm{kg} \mathrm{ha}^{-1}$ of SP-36 and $50 \mathrm{~kg} \mathrm{ha}^{-1}$ of $\mathrm{KCl}$. Urea and $\mathrm{KCl}$ were applied twice at 7 and 30 days after transplanting (DAT). SP-36 was applied only once at 7 days after transplanting (DAT). During the cultivation stage, fungicide for blast disease was not applied.

\section{Sampling and Analysis Methods}

Soil analysis for available $\mathrm{Si}$ for initial soil was analyzed using the acetate buffer method (Imaizumi and Yoshida, 1958 as cited in Darmawan et al., 2006) and the extraction was measured using atomic absorption spectrophotometer (Z-5000; Hitachi, Tokyo, Japan). Paddy leaf samples, the Y-leaf (youngest mature leaf blade) were taken at 50 DAT, 90 DAT, and harvest for and analyzed for total $\mathrm{Si}$. Rice grain samples were analyzed for $\mathrm{Cu}, \mathrm{Fe}, \mathrm{Mn}$, and $\mathrm{Zn}$ contents.

The lodging resistance parameter was assessed with using Force Gauge. Referring to Yoshinaga (2005), the stem was bent at $15 \mathrm{~cm}$ from the surface of the soil to form $45^{\circ}$ angle for lodging resistance assessment. This assessment was conducted at 75 DAT and before harvesting (115 DAT). Observation for blast disease was conducted at 30 and 60 DAT for leaf blast and 75 DAT and 115 DAT for neck blast. Leaf blast disease infection was observed using score value by IRRI System (IRRI, 2002).

Statistic analysis was conducted with two way analysis of variance (ANOVA) and followed with Tukey's test $(p<0.05)$. The effect of silica fertilizer application was analyzed with the student's t-test $(p<0.01)$. SPSS 20.0 was used for statistical analysis.

\section{RESULTS AND DISCUSSION}

\section{Plant Growth}

The effects of water management and Si application on plant growth in term of root weight, shoot weight, number 
of tillers and plant height were shown in Table 1. The result showed that IT increased on root and shoot weight and plant height compared to $\mathrm{CF}$ and $\mathrm{AR}$ water management treatment. Regarding Si application, it has no significant influence on root weight, number of tillers, and plant height but it significantly increased shoot weight $(\mathrm{p}<0.01)$.

The improvement in root weight on IT management as shown in this present study (Table 1) might be due to better soil aeration where optimal water and oxygen are available. Improving on soil aeration could have promoted a great number of whitish, healthy, and well-functioning roots (Chapagain et al., 2011). Meanwhile, AR management tends to have the lowest plant growth compared to IT and CF. Aerobic soil conditions and emerging water shortage could affect the nutrient dynamic in the soil which could give influence on plant growth.

The present result of Si application showed a significant effect on increasing shoot weight at CF and IT and this result is in line with Sugiyanta et al. (2018). The shoot including the stem is one of the factors that affects lodging resistance, as stated by Kong et al. (2013), susceptibility of lodge variation could be determined by stem morphology (weight and height) and plant height. However, the study showed Si application did not stimulate a significant effect on improving lodging resistance (Figure 2).

The improvement of root growth of rice in IT might lead to improvement of shoot weight and plant height (Table 1). Larger root systems on rice plants would enhance water and nutrients uptake for higher shoot weight and plant height. The intermittent watering could enhance the nutrient availability such as nitrogen which has a function to promote the growth of vegetative organs such as leaves, stem, and also to stimulate the root growth (Bloom, 2015).

\section{Lodging Resistance}

At 75 DAT, the lodging resistance of rice at IT watering management increased as compared to $\mathrm{CF}$ and $\mathrm{AR}$ irrespective $\mathrm{Si}$ applications (Figure 1). IT could increase lodging resistance by up to 70 and $75 \%$ under sub plots as $\mathrm{Si}+$ and $\mathrm{Si}-$, respectively. Similar pattern also occurred at harvesting stage observation. This condition might be affected by the better root growth of IT (Table 1). In agreement with previous research, intermittent is appropriate water management for better root and shoot growth of rice (Mishra, 2012) and this could increase lodging resistance in the present study.

\section{Micro Nutrient Content in Rice Grain}

IT treated plants produced grains with the highest concentration of $\mathrm{Cu}, \mathrm{Mn}$, and $\mathrm{Zn}$ as compared to $\mathrm{CF}$ and AR (Figure 2). The shifting from anaerobic to aerobic in IT could enhance micronutrients availability, it might be due to increasing of nutrients solubility in the soil as well as better root uptake.

The highest $\mathrm{Cu}$ concentration in grain appeared under IT followed by CF then AR. The shifting from flooding to aerobic condition in IT might have changed the Eh that either increase the availability of $\mathrm{Cu}$ and $\mathrm{Zn}$ or inhibit the toxicity of $\mathrm{Fe}$ and $\mathrm{Mn}$ reduction. Therefore, $\mathrm{Cu}$ availability in soil increases and it will improve the plant uptake and as a result it will increase $\mathrm{Cu}$ content in rice grain.

The Fe concentration in rice grain decreased sharply from CF to IT and to AR management (Figure 2). The average Fe concentration in rice grain at CF was $75.2 \pm 45.9 \mathrm{mg} \mathrm{kg}^{-1}$, $58.2 \pm 1.9 \mathrm{mg} \mathrm{kg}^{-1}$ at IT then decreased to $38.5 \pm 7.8 \mathrm{mg} \mathrm{kg}^{-1}$

Table 1. The effect of treatments on rice plant growth parameter at harvesting

\begin{tabular}{|c|c|c|c|}
\hline \multirow{2}{*}{ Si level } & \multicolumn{3}{|c|}{ Water management } \\
\hline & $\mathrm{CF}$ & IT & AR \\
\hline \multicolumn{4}{|c|}{ Root fresh weight(g) } \\
\hline $\mathrm{Si}+$ & $20 \pm 4.3 \mathrm{ab}$ & $23 \pm 3.6 b$ & $18 \pm 1.9 \mathrm{a}$ \\
\hline Si- & $19 \pm 1.7 \mathrm{ab}$ & $22 \pm 1.5 b$ & $17 \pm 1.8 \mathrm{a}$ \\
\hline \multicolumn{4}{|c|}{ Shoot fresh weight (g) } \\
\hline $\mathrm{Si}+$ & $82 \pm 4.4 \mathrm{a}^{* *}$ & $89 \pm 4.3 b^{* *}$ & $79 \pm 5.1 \mathrm{a}$ \\
\hline Si- & $73 \pm 5.6 \mathrm{a}^{* *}$ & $81 \pm 4.9 b^{* *}$ & $76 \pm 7.8 \mathrm{a}$ \\
\hline \multicolumn{4}{|c|}{ Number of tillers } \\
\hline $\mathrm{Si}+$ & $11 \pm 0.4 \mathrm{a}$ & $11 \pm 1.1 \mathrm{a}$ & $10 \pm 1.3 \mathrm{a}$ \\
\hline Si- & $10 \pm 0.8 \mathrm{a}$ & $10 \pm 1.3 \mathrm{a}$ & $9 \pm 0.6 \mathrm{a}$ \\
\hline \multicolumn{4}{|c|}{ Plant height $(\mathrm{cm})$} \\
\hline $\mathrm{Si}+$ & $84 \pm 2.9 \mathrm{a}$ & $88 \pm 2.4 b$ & $84 \pm 1.8 \mathrm{a}$ \\
\hline Si- & $82 \pm 0.7 \mathrm{a}$ & $86 \pm 1.7 b$ & $83 \pm 1.2 \mathrm{a}$ \\
\hline
\end{tabular}

Notes: Values followed by similar alphabet is statistically similar at $\alpha=5 \%$. ** Significantly different at $\mathrm{p}<0.01$ among Si treatments 
CF : Continuous Flooding

IT : Intermittent

AR : Aerobic Rice

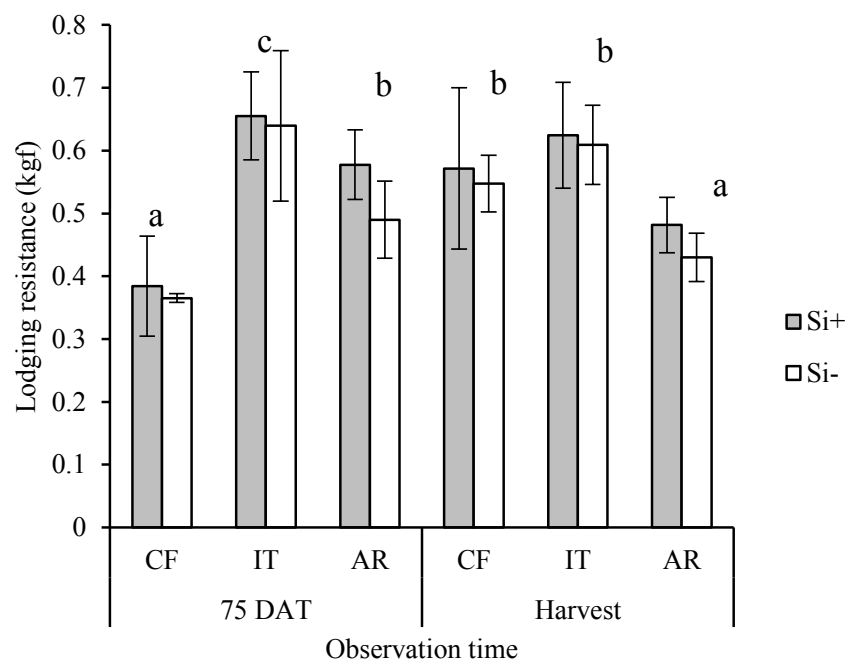

Figure 1. Influence of treatments on lodging resistance. Different letters indicate statistically different among water treatments. Each value is the mean $\pm \mathrm{SD}$

at $\mathrm{AR}$ for $\mathrm{Si}+$ treatment and similar pattern also occurred within water management under Si- treatment (Figure 2). This condition could be related to the solubility of Fe in soil, as stated by Fan et al. (2012) that aerobic condition will reduce Fe allocated in rice grain due to low availability of Fe in aerobic soil. The solubility of Fe is low in AR due to formation of Fe hydroxides, oxyhydroxides, and oxides which exhibited high stability (Mielki et al., 2016) and it will influence plant uptake and Fe content in rice grain.

Regarding $\mathrm{Zn}$ concentration in rice grain, the highest $\mathrm{Zn}$ concentration was found on IT treatments and the level was significantly different from conventional water management (CF) (Figure 2). Hawkesford and Barraclough (2011) noted that in $\mathrm{CF}$ condition soil $\mathrm{pH}$ tends to increase and stimulates $\mathrm{Zn}$ fixation into soil as metal oxides and clay minerals, resulting in lower $\mathrm{Zn}$ concentration both in soil and plant tissues.

\section{Rice Blast Disease}

There was a significant effect $(\mathrm{p}<0.01)$ of Si application on decreasing blast disease both on leaf and neck blast in CF, IT and AR treatments (Figure 3 and 4). Leaf blast decreased by 42,30 , and $32 \%$ at 30 DAT and 43,69 , and $62 \%$ at 60 DAT for CF, IT and AR water management treatments, respectively. Furthermore, neck blast infection showed the same trend to leaf blast where the diseases decreased significantly $(p<0.01)$ by the application of $\mathrm{Si}$ fertilizer (Figure 4). Water management also could decrease blast disease significantly along the observation time.

Decreasing of blast infection (Figure 3 and 4) could be related to Si content in rice leaves, as this present study showed an increasing in Si content by fertilizer treatment (Figure 5). It is probable that $\mathrm{Si}$ was absorbed by the roots and translocated to the plant tissue. According to Marschner (2012), Si layer will protect and increase plant resistance against fungi and bacteria infections.

Generally, IT treated plants had lower blast disease infection. This could be related to environmental conditions at IT, as it has shifted anaerobic-aerobic situation which is unsuitable for the life-cycle of the fungi of blast disease (Chapagain et al., 2011). The result showed that higher Si content in IT was followed by lower blast infection as compared to the other watering treatments. It clearly proved the role of $\mathrm{Si}$ as a physical barrier to prevent blast infection and it was supported by the significant correlation between Si content in leaves and blast infection (Figure 6). Increasing Si content in leaves would decrease blast infection.

Moreover, it was noticed that $\mathrm{CF}$ treated plants tend to have the lowest $\mathrm{Si}$ content as compared to IT and AR in both $\mathrm{Si}+$ and $\mathrm{Si}$ - treatments (Figure 5). As the soil in

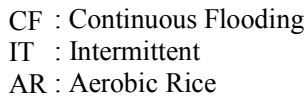

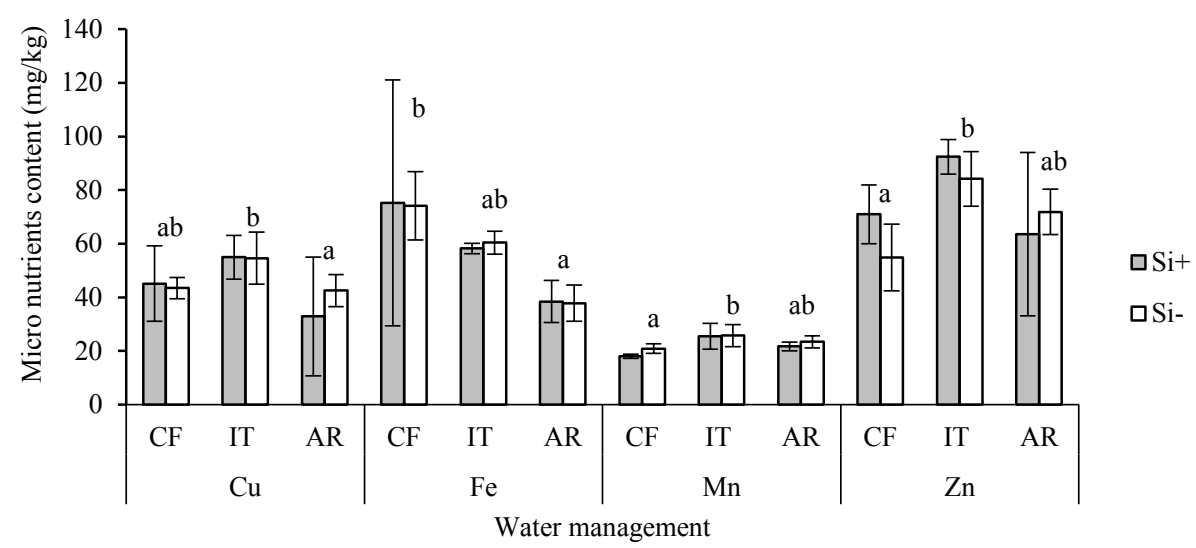

Figure 2. Influence of treatments on micronutrients concentration in rice grain. Different letters indicate statistically different among water treatments. Each value is the mean $\pm \mathrm{SD}$ 


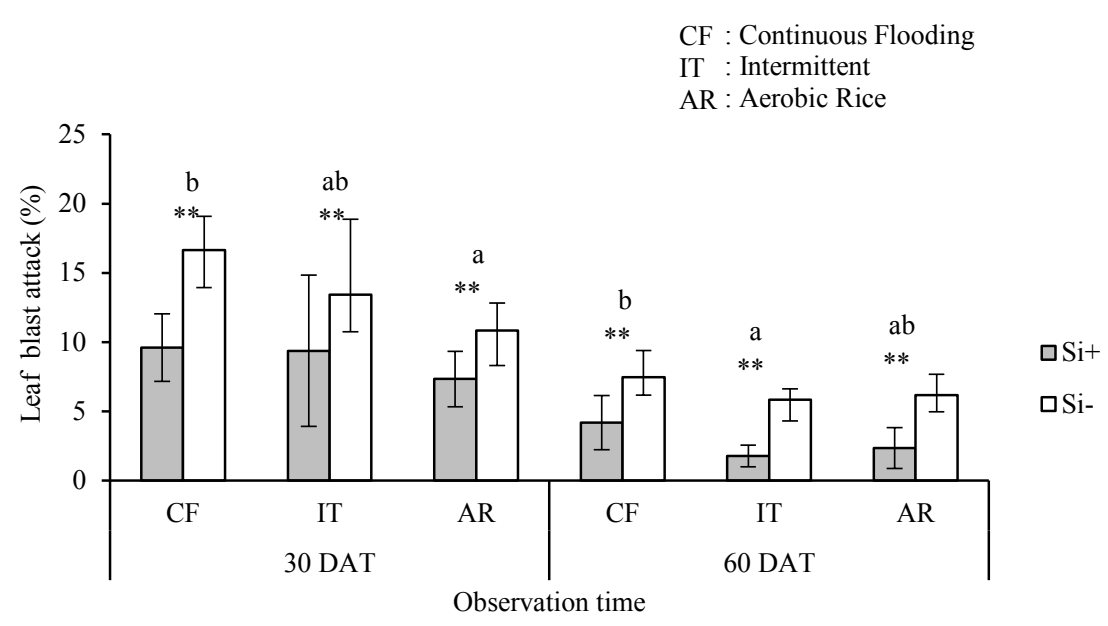

Figure 3. Influence of treatments on leaf blast infection. Different letters indicate statistically different among water treatments. ** Significantly different at $\mathrm{p}<0.01$ between $\mathrm{Si}$ treatments. Each value is the mean $\pm \mathrm{SD}$

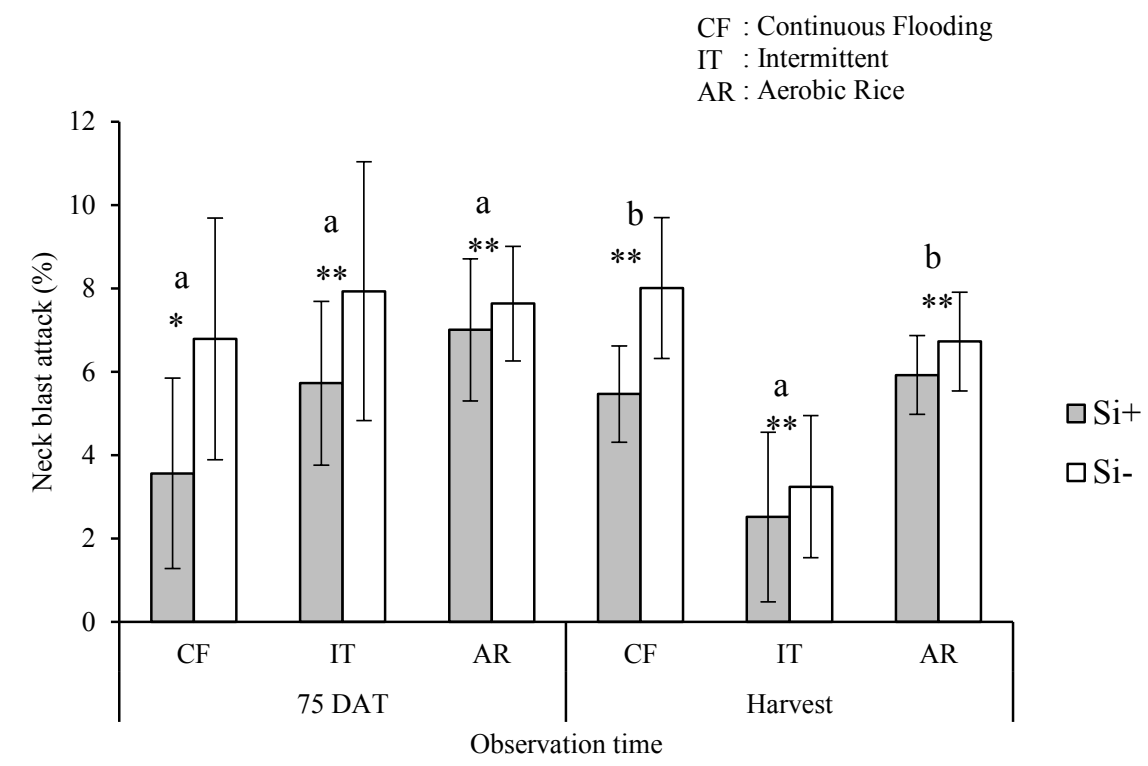

Figure 4. Influence of treatments on neck blast infection. Different letters indicate statistically different among water treatments. ** Significantly different at $\mathrm{p}<0.01$ between $\mathrm{Si}$ treatments. Each value is the mean $\pm \mathrm{SD}$

$$
\begin{aligned}
& \text { CF : Continuous Flooding } \\
& \text { IT : Intermittent } \\
& \text { AR : Aerobic Rice }
\end{aligned}
$$

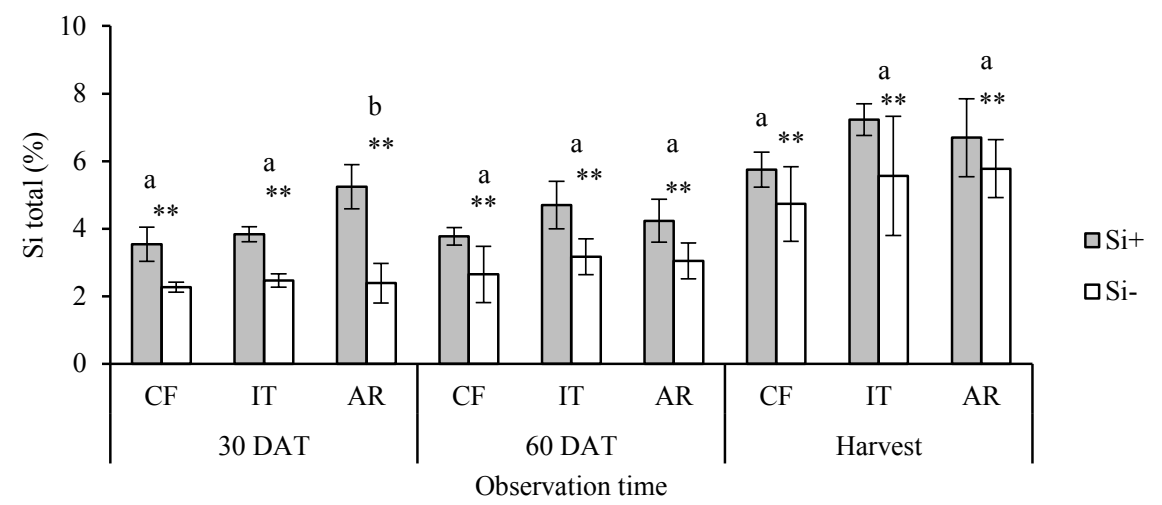

Figure 5. Influence of treatments on Si content in rice leaves. Different letters indicate statistically different among water treatments. $* *$ Significantly different at $\mathrm{p}<0.01$ between $\mathrm{Si}$ treatments. Each value is the mean $\pm \mathrm{SD}$ 
reductive condition at $\mathrm{CF}$ field, the $\mathrm{Si}$ in the soil solution may have been co-precipitated with $\mathrm{Fe}$ oxides/hydroxides (Schwertmann, 1991). Therefore, Si uptake by rice plant was smaller as compared to IT and AR fields.

\section{Yield}

Under IT treatment, rice yield increased by 5.7 and $5.2 \%$ from $\mathrm{CF}$ and $\mathrm{AR}$ supplemented with $\mathrm{Si}$, while it increased by 15 and $6 \%$ from CF and AR treatments without $\mathrm{Si}$, respectively. Here, water management determined nutrients availability to achieve high yield. IT treated plants showed improvement on root growth as compared to other water treatments (Table 1). Better root system in rice under

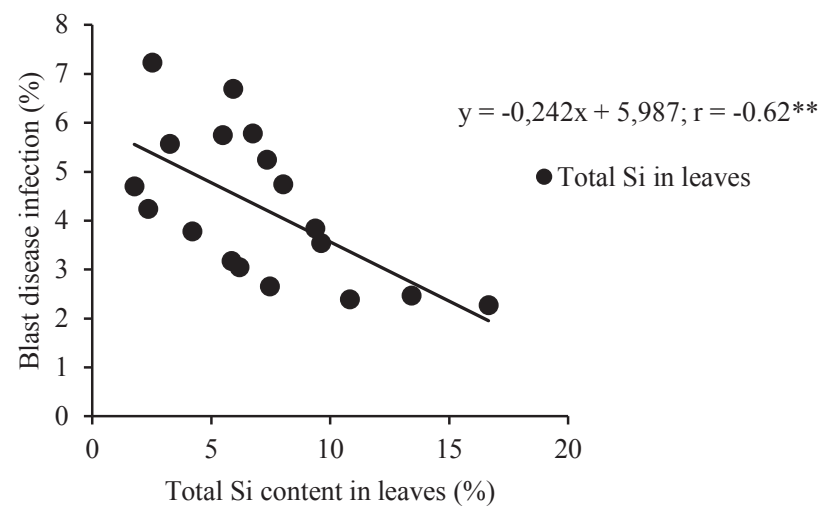

Figure 6. Correlation between total Si content in leaves with blast infection $* *$ significant, $\mathrm{p}<0.01$

\section{CONCLUSION}

Intermittent (IT) watering management significantly increased rice yield and quality than conventional practice (CF). The increasing yield could associate with improvement of root growth, shoot weight, plant height and lodging resistance. Si level in the leaves reduce leaf and neck blast infection, reducing empty rice grain percentage and improvement on $\mathrm{Cu}, \mathrm{Mn}$ and $\mathrm{Zn}$ concentration in rice grain. Application of Si promoted blast disease resistance of rice plant. IT treatment in combination with Si application could improve rice production in blast endemic area and limited water availability.

\section{ACKNOWLEDGEMENT}

This work was supported by JSPS KAKENHI Grant Number 24405047 and 25257405.

\section{REFERENCES}

Arif, C., B.I. Setiawan, H.A. Sofiyuddin, L.M. Martief. 2013. Enhanced water use efficiency by intermittent irrigation for irrigated rice in Indonesia. J. Islamic Persp. Sci. Tech. Soc. 1:12-17.
IT enable the plants to access more water and nutrients, resulting in IT plants have the highest leaf area (Pascual and Wang, 2016). These improvements will contribute to increasing photosynthetic rate then manifest on improving the yield.

Soil under IT repeatedly experienced submerged and aerobic condition which led to a variation of $\mathrm{N}$ available form as $\mathrm{NH}_{4}^{+}$and $\mathrm{NO}_{3}^{-}$in the soil solution. This condition enhanced by $40-60 \%$ of rice production compared to having $\mathrm{N}$ available only in $\mathrm{NH}_{4}^{+}$form as in $\mathrm{CF}$. The continuous flooding field reduces soil $\mathrm{N}$ availability (Nguyen et al., 2018). Finally, higher yield under IT treated could be due to aerobic condition that stimulating soil microorganism growth and activities.

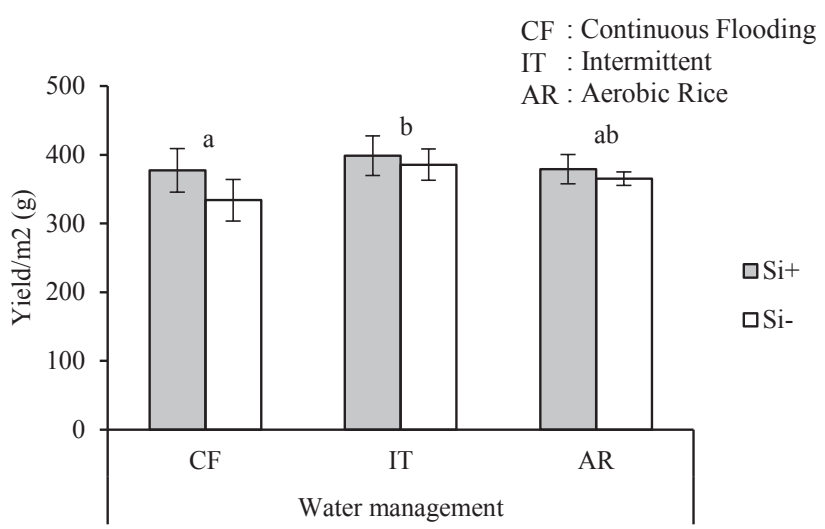

Figure 7. Influence of treatments on rice yield. Different letters indicate statistically different among water treatments. Each value is the mean $\pm \mathrm{SD}$

Bloom, A.J. 2015. The increasing importance of distinguishing among plant nitrogen sources. Curr. Opinion Plant Biol. 25:10-16. Doi:10.1016/ J.PBI.2015.03.002.

Chapagain, T., A. Riseman, E. Yamaji. 2011. Achieving more with less water: alternate wet and dry irrigation (AWDI) as an alternative to the conventional water management practices in rice farming. J. Agric. Sci. 3(3). Doi:10.5539/jas.v3n3p3.

Darmawan, K. Kyuma, A. Saleh, H. Subagjo, T. Masunaga, T. Wakatsuki. 2006. Effect of long-term intensive rice cultivation on the available silica content of sawah soils : Java Island, Indonesia. Soil Sci. Plant Nutr. 1: 745-53. Doi:10.1111/j.1747-0765.2006.00089.x.

Fan, X., M.R. Karim, X. Chen, Y. Zhang, X. Gao, F. Zhang, C. Zou. 2012. Growth and iron uptake of lowland and aerobic rice genotypes under flooded and aerobic cultivation. Comm. Soil Sci. Plant Anal. 43:18111822. Doi:10.1080/00103624.2012.684826.

Guntzer, F., C. Keller, J.D. Meunier. 2012. Benefits of plant silicon for crops: A review. Agron.Sustain.Dev 32: 201-213. Doi:10.1007/s13593-011-0039-8. 
Hawkesford, M.J., P. Barraclough. 2011. Zinc in soils and crop nutrition. p. 335-375. In B. Sadeghzadeh, Rengel $\mathrm{Z}(E d s)$. The molecular and physiological basis of nutrient use efficiency in crops. Wiley-Blackwell, Oxford, UK.

IRRI. 2002. Standard evaluation system for rice (SES). http://www.knowledgebank.irri.org/images/docs/ rice-standard-evaluation system.pdf [1 September 2015].

Kong, E., D. Liu, X. Guo, W. Yang, J. Sun, X. Li, K. Zhan, D. Cui, J. Lin, A. Zhang. 2013. Anatomical and chemical characteristics associated with lodging resistance in wheat. Crop J. 1: 43-49. Doi:10.1016/ j.cj.2013.07.012.

Marschner, P. 2012. Mineral nutrition of higher plants. London: Academic Press, London, GB.

Mielki, G.F., R.F. Novais, J.C. Ker, L. Vergutz, G.F. Castro. 2016. Iron availability in tropical soils and iron uptake by plants. Rev. Bras. Cienc. Solo. 40:e0150174.

Mishra, A. 2012. Intermittent irrigation enhances morphological and physiological efficiency of rice plants. Agriculture 58:121-30. Doi:10.2478/v10207012-0013-8.

Nguyen, L.T.T., Y. Osanai, A.C. Anderson, M.P. Bange, M. Braunack, D.T. Tissue, B.K. Singh. 2018. Impacts of waterlogging on soil nitrification and ammoniaoxidizing communities in farming system. Plant Soil. 426:1-13. Doi:10.1007/s11104-018-3584-y.

Pascual, V., Y.M. Wang. 2016. Impact of water management on rice varieties, yield, and water productivity under the system of rice intensification in Southern Taiwan. Water 9:3. Doi:10.3390/w9010003.

Rahman, S.M., K. Kakuda, Y. Sasaki, H. Ando. 2013. Effect of mid season drainage (MSD) on growth and yield of rice in North East Japan. Amer. J. Plant Nutr. Fert. Technol. 3:33-42.

Salman, D., S. Morteza, Z. Dariush, A. Nasiri, Y. Reza, G. D. Ehsan, N.N.A. Reza. 2012. Application of nitrogen and silicon rates on morphological and chemical lodging related characteristics in rice (Oryza sativa L.) at North of Iran. J. Agric. Sci. 4:1218. Doi:10.5539/jas.v4n6p12.

Sugiyanta, I.M. Dharmika, D.S. Mulyani. 2018. Pemberian pupuk silika cair untuk meningkatkan pertumbuhan, hasil dan toleransi kekeringan padi sawah. J. Agron. Indonesia. 46:153-160. Doi:10.24831/jai. v46i2.21117.

Schwertmann, U. 1991. Solubility and dissolution of iron oxides. Plant and Soil 130:1-25. Doi:10.1007/ BF00011851.

Yoshinaga, S. 2005. Improved lodging resistance in rice (Oryza sativa L.) cultivated by submerged direct seeding using a newly developed hill seeder. Japan Agric. Res. Quart. 39:147-52. Doi:10.6090/ jarq.39.147.

Zhang, H., H. Li, L. Yuan, Z. Wang, J. Yang, J. Zhang. 2012. Post-anthesis alternate wetting and moderate soil drying enhances activities of key enzymes in sucroseto-starch conversion in inferior spikelets of rice. J. Exp. Bot. 63:215-27. Doi:10.1093/jxb/err263. 